\title{
INFORMATION ASYMMETRIES IN THE COMMUNICATION BETWEEN BUREAUCRACY AND Citizens
}

\author{
CLAUDIA LUBK*
}

\section{INTRODUCTION}

The public sector is one of the most important employers worldwide. Within many OECD countries, public sector employment amounts to more than 20\% (e.g., Sweden, Poland, Great Britain) or even 30\% (Norway, Denmark) of the total labour force. The OECD average is over $19 \%$; only in Japan and Korea public sector employment is responsible for less than $10 \%$ of total employment. ${ }^{1}$ In Germany, more than 5.8 million persons, i.e., roughly $13 \%$ of the total labour force, is employed in the public sector ${ }^{2}$. The annual budget of the German public sector in 2016 is estimated at 316 billion $\mathrm{EUR}^{3}$, and it is virtually impossible to not be in contact with any public authorities as a German citizen - the same goes, possibly to a higher or lesser extent, for many other countries. At the same time, surveys among citizens aimed at analyzing their satisfaction with the public sector in general, and civil servants in particular, show a continuing or, in some cases, even an increasing, dissatisfaction with the contact between the public and the administration. Data for Germany showing that in 2016, 74\% of the citizens answering a questionnaire agreed that civil servants are conscientious (2009: 79\%) and 65\% consider them to be competent or rather competent (2009: 64\%), implies that $26 \%$ resp. $35 \%$ of the citizens do not share the positive impression. In addition, civil servants are often considered corrupt, arrogant, and even superfluous. The specific assessment varies among the occupational groups among the civil servants, though. While firemen and medical personnel as well as (to a slightly smaller degree) teachers and professors are highly estimated $(75-90 \%$ of those surveyed

\footnotetext{
DOI: $10.1515 /$ wrlae-2015-0058

* Professor for Public Management, $\mathrm{PhD}$ in Economics, Department of General Administration, Meissen University of Applied Administrative Sciences, Centre for Continuing Education; claudia.lubk@hsf.sachsen.de

${ }^{1}$ OECD, Government at a Glance 2015 (OECD Publishing 2015) 85.

2 Statistisches Bundesamt, 'Finanzen und Steuern. Personal des Öffentlichen Dienstes 2015' 2016, data of the German Bureau of Statistics; this includes civil servants in the core administration on the federal, state and communal level, employees in public foundations etc., as well as employees in public enterprises.

3 Bundesregierung, 'Bundeshaushalt' $2016<$ www.bundeshaushalt.de $>$ (German Federal Budget) accessed 9 Dec 2016.
} 
stated a high regard for those professions), civil servants of the fiscal authorities, e.g., are only regarded highly by $29 \%{ }^{4}$.

As the contact between citizens and the administration is highly relevant for a utilisation of public offers by citizens, the effectiveness of measures depends to no small amount on this contact. In addition, for many citizens, the administration is equivalent to the government. Citizens tend to attribute the (perceived) failures of public services to politicians ${ }^{5}$ - making a good image and effective functioning of the administration important with regards to democracy and transparency ${ }^{6}$.

To explain communication between citizens and bureaucracy, and to improve their interaction and thereby the efficiency and effectiveness of their interaction, economic theory offers various insights. In cases where governments take action to reduce information asymmetries or to correct problems occurring due to information asymmetries, economic theory is still somewhat restricted in explaining the utility of such interventions. Public choice theory discusses interactions between the public sector and stakeholders with the assumption of rational agents and does not focus on information asymmetries. Institutional Economics, on the other hand, may prove helpful in analyzing the necessity and possible success of such actions; another field of applicable research is likely the study of cultural and behavioural economics. ${ }^{7}$ E.g., the principal-agent model and the corresponding aspects of information asymmetries may be useful in explaining friction between the stakeholders and lead to a better understanding of possible solutions to the problem.

In the following text, bureaucracy and (public) administration shall be used synonymously, i.e., civil servants and employees of the public administration in general are synonymously described as bureaucrats.

\section{BUREAUCRACY}

Stemming from the words bureau (for desk, i.e., the working place of the administration) and kratein (Greek for ruling, controlling), the first use of the word is attributed to the French economist Vincent de Gournay who coined it in the middle of the $18^{\text {th }}$ century. ${ }^{8}$ Since then, a large number of scientists, mostly sociologists, but also economists and political scientists, have analysed the public sector and its employees, and developed extensive theories. While some of their findings still influence today's

\footnotetext{
4 forsa, Bürgerbefragung Öffentlicher Dienst: Einschätzungen, Erfahrungen und Erwartungen (dbb verlag 2016) 7-11.

${ }^{5}$ Oliver James, Sebastian R Jilke, Carolyn Petersen, Steven Van de Walle, 'Citizens' Blame of Politicians for Public Service Failure: Experimental Evidence about Blame Reduction through Delegation and Contracting' (2015) 76(1) Public Administration Review 83.

${ }^{6}$ Hans-Ulrich Derlien, Doris Böhme, Markus Heindl, Bürokratietheorie: Einführung in eine Theorie der Verwaltung (VS Verlag für Sozialwissenschaften 2011) 190.

${ }^{7}$ Stefan Mann, Henry Wüstemann, 'Public Governance of Information Asymmetries-The Gap Between Reality and Economic Theory’ (2010) 39 The Journal of Socio-Economics 278 .

${ }^{8}$ Nathalie Behnke, Bürokratie und Verwaltung', in Steffen Mau, Nadine M. Schöneck (eds), Handwörterbuch zur Gesellschaft Deutschlands (Springer Fachmedien 2013) 130.
} 
management of the administration and have an effect on the image of the civil servants in the eyes of the public, newer theories need to deal with a changing reality, more complex regional and global requirements, changed demands of the citizens and, last but not least, the demographic development ${ }^{9}$.

The classical image of a bureaucrat is strongly influenced by Max Weber's theory of bureaucracy. He describes the characteristics necessary in a bureaucrat as follows: they must be impartial, base their actions solely on rules, be objective, assessable, and be able to separate the incumbent and the resources. In short, Weber considered bureaucracy as an impartial agent to the legislative. ${ }^{10}$

Ludwig von Mises expanded the theory by stating that as bureaus supply services where the value cannot be calculated in monetary unit prices, and economic calculation cannot be used as a guiding principle, bureaus must therefore be centrally managed by regulation and monitoring. ${ }^{11}$ His widely acknowledged work stressed that the perception of bureaucracy is negative and goes on to analyse the shortcomings of the bureaucratic system.

A few decades later, William A. Niskanen was the first to discuss bureaucracy based on the theory of the firm and analysed the characteristics of bureaus, the relation between bureaus and their environment and the aspects that bureaucrats aim to maximise. He defines bureaus as non-profit organisations which are at least partly financed not by selling output at a unit price, but rather by a budget. ${ }^{12}$ He defines the variables the bureaucrat aims to maximise as the follows: "salary, perquisites of the office, public reputation, power, patronage, ease of managing the bureau, and ease of making changes" $" 13$, i.e., in general, they are maximising their budget.

\section{The Principal-Agent-Model}

With his theory, Niskanen contradicts Weber's theory, as in his analysis, the bureaucrat has his own subjective interests, causing frictional losses in the process of the administration. Thus, the bureaucrat is no longer a mere servant following the rules, but rather an agent with own interests. The field of New Institutional Economics addresses such interactions with the help of the so-called principal-agent model. The model is used to describe interactions of a principal who employs an agent to act in his interest. Due to information asymmetries, i.e., one party possessing information the other does not, the principal cannot monitor or judge the quality of the agent's actions, and the agent acts under the aspect of

\footnotetext{
${ }^{9}$ On the impact of the demographic change on the administration in the Freestate of Saxony cf., e.g., Frank Nolden in this volume.

${ }^{10}$ Weber Max, Grundriß der Sozialökonomik: III. Abteilung Wirtschaft und Gesellschaft (J C B Mohr Paul Siebeck 1922) 650 et seq.

${ }_{11}^{1}$ Ludwig von Mises, Bureaucracy (Yale University Press) 1944.

12 William A Niskanen, Ein Ökonomisches Modell der Bürokratie. Aus dem Englischen übersetzt und leicht gekürzt von Charles B Blankart, in Werner W. Pommerehne, Bruno S Frey (eds), Ökonomische Theorie der Politik (Springer 1979).

13 William A Niskanen, 'The Peculiar Economics of Bureaucracy' (1968) 58(2) The American Economic Review 293.
} 
maximising his own utility ${ }^{14}$. Typical examples for information asymmetries are hidden characteristics (often leading to adverse selection ${ }^{15}$ ), hidden action, hidden information, both often connected with moral hazard, and hidden intentions ${ }^{16}$.

The German basic law states in art $20 \mathrm{sec} 1 \mathrm{cl} 2$ that "all state authority is derived from the people. It shall be exercised by the people through elections and other votes and through specific legislative, executive and judicial bodies"17. This, in the democratic reality, leads to a multilayered chain of democratic delegation. Considering the typical connections between citizens, the government and the administration, one finds a multistep process. Citizens will elect their members of parliaments (or, on other levels of government, local representatives, etc.) according to their preferences, thereby acting as principals authorising the agents to act in their interest. The members of parliament in turn elect the head of government who then has the right to appoint ministers, which again act as agents to the head of government as the agent. The legislature, consisting of the parliaments and the head of government with the ministers, passes bills and regulations which are then passed on to the administration (as the agent to the legislature principal) to realise their implementation. In the administration itself, there are various hierarchical levels, again leading to various steps of principal-agent relationships. The citizen is not able to monitor the process of political decisions and implementation completely, but only sees the outcome. In this multi-layered principal-agent model, there are all kinds of information asymmetries, divergences of interests and monitoring problems, and the citizen does not know whether the outcome is in spite or because of the efforts of the elected agents. Considering that there are information asymmetries on every step of the model, the whole process becomes a highly complex structure where the outcome can only partly be influenced on every level. Therefore, the citizen sees an outcome in which he tends to contribute to the civil servants actions, but which may well be determined by the many decision levels above. At the same time, the civil servant with his own interests such as those defined by Niskanen or an interest in minimising his workload and therefore, e.g., offering only limited advice, can influence the final outcome of a measure.

\section{THE INTERACTION BETWEEN CITIZEN AND BUREAUCRACY}

As mentioned above, the citizen's direct contact with the political and administrative system is mainly through interaction with the administration.

\footnotetext{
${ }^{14}$ The origins of the principal-agent models are mainly attributed to Michael C. Jensen, William H. Meckling, (1976).

15 George Akerlof, "The Market for "Lemons": Quality Uncertainty and the Market Mechanism' (1976) 89 Quarterly Journal of Economics 488.

${ }^{16} \mathrm{Cf}$. the work of Agnieszka Chrisidu-Budnik and Justyna Przedańska in this volume.

${ }^{17}$ Basic law for the FRG, translated by Christian Tomuschat and Donald P Kommers, cf. https://www.gesetze-im-internet.de/englisch_gg/englisch_gg.html\#p0111
} 
The expectations regarding the services provided by the public administration are shaped not only by prior experiences, but also in comparison to the private sector. ${ }^{18}$ The high quality of services, the promptitude and the importance placed on the customer and his wishes in commercial transactions lead to corresponding demands in the public sector.

Surveys on the satisfaction of citizens with public services show the following results: on a scale from +2 (very satisfied) to -2 (very dissatisfied), German citizens rate their overall satisfaction with the public administration at 1.06, which is a rather positive result. It has to be stated though, that the satisfaction clearly varies between the services used. The highest satisfaction rate can be seen regarding marriage-related services (satisfaction: 1.46), whereas the satisfaction with services and consultations concerning unemployment and financial problems is considerably lower, if still positive, at a satisfaction average of $0.37 .^{19}$

The most important aspects for citizens as customers of the public administration are trust, non-discrimination, incorruptible civil servants and expertise in the field of consultation. The least satisfaction was indicated with the understandability of the laws and regulations as well as the comprehensibility of the forms and applications. In this case as well, there are considerable differences in the various fields of service; e.g., when applying for drivers licences, the satisfaction with the comprehensibility of regulations and forms is 1.22 , whereas the satisfaction regarding situations where citizens face financial problems is at only $-0.08 .{ }^{20}$

Another survey showed that the points that were mostly criticised on the communal level were suboptimal opening hours, to long timeframes for the processing of applications, a lack of clarity regarding the appropriate contact person, and services that are not customer-, i.e., citizen-oriented. ${ }^{21}$ The last aspect must be discussed with the background that the equal treatment and the strict following of rules is also intended to protect the citizens by providing services without regard to the person, with legal certainty and predictability of outcomes, though. ${ }^{22}$

At the same time, the civil servants have to deal with a heterogeneous clientele with heterogeneous demands, while observing the precept of non-discrimination. An analysis of citizens classifies them into the following groups: the "helpless subject", the "competent pragmatic", the "identified technocrat", the blind bureaucrat, the insecure frustrated citizen, the estranged citizen, and the competent critic of the system. ${ }^{23}$ While this classification may be clichéd and simplified, it contains a number of characteristics that civil servants have to observe. The level of information of the citizens before a consultation varies highly, as do the understanding

\footnotetext{
18 Robert Knappe, Die Eignung von New Public Management zur Steuerung Öffentlicher Kulturbetriebe (Gabler Verlag 2010).

19 Statistisches Bundesamt, Bürger sind mit ihrer Öffentlichen Verwaltung Überwiegend Zufrieden: PM 298/15 (2015) 1.

20 ibid.

${ }^{21}$ Claus Stickler, Veränderungsprozesse in der Kommunalverwaltung: Ziele, Inhalte und Methoden (Deutscher Universitätsverlag 2000) 17-18.

${ }^{22}$ Derlien, Böhme, Heindl (n 7) 199.

${ }^{23}$ Pippig Gerhard, Die Verwaltung und ihr Publikum: Psycho-Strukturelle Bedingungen und Klientenorientierung der Öffentlichen Verwaltung (Beiträge zur sozialwissenschaftlichen Forschung 107, VS Verlag für Sozialwissenschaften 1988) 157.
} 
of administrative processes, the self-confidence and the demands on the administration. In all cases, the administrative staff has to consult to the best of their knowledge ${ }^{24}$ while observing the non-discrimination precept.

\section{Challenges for the Administration}

The citizen's wishes regarding personalized consultations, problemand service-oriented civil servants, direct communication and simplified forms are in stark contrast with the bureaucrat's preferences for impersonal counselling that is governed by an obedience of rules to avoid mistakes and ensure equal treatment.

In addition to those differences in preferences, the public administration faces three important challenges: the financial gap, an acceptance gap and a modernisation gap ${ }^{25}$.

The financial gap describes the situation especially on the community level, where the budgets are insufficient to cover the current spending. Therefore, many communes are indebted, which in turn leads to an even more restricted scope of action and a possible limitation especially of the optional task, but also to a limited quality of the provision of the mandatory tasks. The reasons for the discrepancy between budget and spending are mainly high investments and deficits in the budgets for the administration itself. These deficits are caused by additional tasks such as the increased demands on quality and quantity of childcare.

Generally, the consequences of the financial gap are either a growing debt, decreased spending or efforts to modernise the administration ${ }^{26}$.

The acceptance gap consists mainly of an attractiveness gap, i.e., a low satisfaction of the citizens with the administration as well as a low satisfaction of companies with the bureaucracy and the decreasing interest of potential applicants for the civil service; and a legitimisation gap, i.e. the perceived suboptimal quality, efficiency and effectiveness of public services. The latter aspect is usually addressed by increasing transparency of the decision processes, the scope of services and the evaluation of measures ${ }^{27}$.

The modernisation gap addresses the underlying structural problems of the public administration. These structural deficits are especially noticeable in comparison with structures in the private sector. The structure of the bureaucracy has not changed in parallel to the increasing complexity and dynamic. A transformation and modernisation is complicated by the size of the administration and the established structures. The typical approaches to lessen this gap were the outsourcing of tasks as well as the consolidation of households, i.e., increasing revenues and decreasing expenses $^{28}$.

\footnotetext{
${ }^{24}$ On the citizen's rights to consultation cf. Matthias Thum in this volume.

${ }^{25}$ Stickler (n 22) 7 et seq.

26 ibid. 14-15.

27 ibid. 18-20.

28 ibid. 28-30.
} 


\section{Possible Solutions}

Institutional economics offers a number of solutions for the various information asymmetries. The standard solutions are signalling ${ }^{29}$ (i.e., the agent makes efforts to increase the information of the principal) and screening (i.e., the principal makes efforts to decrease the information asymmetries).

Administrative theory has developed several new concepts in the last decades which address the challenges mentioned above.

The New Public Management is based on an economisation of the administration and focuses on performance orientation, innovation, pragmatic solutions, quality orientation and concentration on the outcome. This may contradict the equal treatment stipulation, though ${ }^{30}$. This theory is criticised because public services cannot always be provided with private business methods, for example because, as mentioned in section 2, the public sector often offers services whose value cannot be measured in monetary unit prices, e.g., because they are public goods or merit goods. In addition, the realisation of some of the aspects led to unclear responsibilities , higher risks of failure on the side of the bureaucrats due to increased scopes of discretion, and possibly a higher susceptibility to corruption ${ }^{31}$.

Public Governance, another approach to a modernisation of the public administration, states the importance of a stronger active participation of citizens and expects the public sector to initiate and moderate the commitment of the citizens ${ }^{32}$.

Ethical management is based on an OECD recommendation and contains hard measures such as regulations, laws and sanctioning, as well as soft instruments such as education, raising awareness, sensitisation to the risk of corruption and conflicts of interests. ${ }^{33}$

There is also the general approach of increasing transparency. This would not only include explaining public decisions, but also the reduction of bureaucratese ("Amtsdeutsch"), the simplification of forms and applications, educating civil servants not only on technical aspects, but also in soft skills. The introduction of e-Government aspects can reduce time for processing requests and waiting times. There are also ombudsmen on several levels that can offer citizens a comparably unbureaucratic possibility to control the administration ${ }^{34}$.

Most of the reforms proposed are only implemented selectively, though. Transformations such as the introduction of e-Government or a reorganisation of the administration hierarchy is costly, which increases the financial gap. In addition, the acceptance of transformations both with the

\footnotetext{
${ }^{29}$ On Signalling, cf., e.g., Michael Spence, 'Job Market Signaling' (1973) 87(3) Quarterly Journal of Economics 355, who explained the theory using the example of the labour market.

${ }^{30}$ Knappe (n 19) 53-55.

${ }^{31}$ Kurt Kippels, Demokratie und Exekutive in Edwin Czerwick, Wolfgang H Lorig Erhard Treutner (eds), Die öffentliche Verwaltung in der Demokratie der Bundesrepublik Deutschland (VS Verlag für Sozialwissenschaften 2009) 17-19.

${ }^{32}$ Knappe (n 19) 92-93.

33 OECD, 'Managing Ethics: An OECD Recommendation' (1998) Public Management Gazette.

${ }^{34}$ Derlien, Böhme, Heindl (n 7) 34.
} 
citizens as well as the bureaucrats is not necessarily high. In addition, a number of studies find that public management reform was often conducted suboptimally, with politicians and top-level civil servants choosing their preferred reform areas and measures while neglecting others ${ }^{35}$.

\section{CONCLUSION}

The satisfaction of citizens with the public administration needs to be improved. Institutional economics and especially the theory of information asymmetries can be used to explain several aspects of the legitimacy gap and, in parts, the modernisation gap. Considering the financial situation on the communal level as well as the demands of the citizens, but also the expected demographic changes, a modernisation and transformation of the administration is inevitable. Such a change must also include civil servants who do not only fulfil Max Weber's requirements for bureaucrats, but are also educated to react flexibly to changes and individual situations of the citizens and who possess the skills to communicate and consult in a way that decreases the gap between citizens and the bureaucracy. The increased demands on bureaucrats' skills are a special challenge taking into consideration the demographic situation in Germany.

\section{References}

Akerlof George, 'The Market for "Lemons": Quality Uncertainty and the Market Mechanism' (1976) 89 Quarterly Journal of Economics

Behnke Nathalie, Bürokratie und Verwaltung', in Mau Steffen, Schöneck Nadine M. (eds), Handwörterbuch zur Gesellschaft Deutschlands (Springer Fachmedien 2013)

Derlien Hans-Ulrich, Böhme Doris, Heindl Markus, Bürokratietheorie: Einführung in eine Theorie der Verwaltung (VS Verlag für Sozialwissenschaften 2011)

James Oliver, Jilke Sebastian R, Petersen Carolyn, Van de Walle Steven, 'Citizens' Blame of Politicians for Public Service Failure: Experimental Evidence about Blame Reduction through Delegation and Contracting' (2015) 76(1) Public Administration Review

Kippels Kurt, Demokratie und Exekutive in Czerwick Edwin, Lorig Wolfgang H, Treutner Erhard (eds), Die öffentliche Verwaltung in der Demokratie der Bundesrepublik Deutschland (VS Verlag für Sozialwissenschaften 2009)

Knappe Robert, Die Eignung von New Public Management zur Steuerung Öffentlicher Kulturbetriebe (Gabler Verlag 2010)

35 Sjors Overman, Marieke Van Genugten, Sandra Van Thiel, 'Accountability After Structural Disaggregation: Comparing Agency Accountability Arrangements' (2015) 93(04) Public Administration 1102. 
Mann Stefan, Wüstemann Henry, 'Public Governance of Information Asymmetries - The Gap Between Reality and Economic Theory' (2010) 39 The Journal of Socio-Economics

Mau Steffen, Schöneck Nadine M. (eds), Handwörterbuch zur Gesellschaft Deutschlands (Springer Fachmedien 2013)

Mises Ludwig von, Bureaucracy (Yale University Press)

Niskanen William A, Ein Ökonomisches Modell der Bürokratie. Aus dem Englischen übersetzt und leicht gekürzt von Charles B Blankart, in Pommerehne Werner W., Frey Bruno S (eds), Ökonomische Theorie der Politik (Springer 1979)

Niskanen William A, 'The Peculiar Economics of Bureaucracy' (1968) 58(2) The American Economic Review

Pippig Gerhard, Die Verwaltung und ihr Publikum: Psycho-Strukturelle Bedingungen und Klientenorientierung der Öffentlichen Verwaltung (Beiträge zur sozialwissenschaftlichen Forschung 107, VS Verlag für Sozialwissenschaften 1988)

Spence Michael, 'Job Market Signaling' (1973) 87(3) Quarterly Journal of Economics

Stickler Claus, Veränderungsprozesse in der Kommunalverwaltung: Ziele, Inhalte und Methoden (Deutscher Universitätsverlag 2000)

Overman Sjors, Van Genugten Marieke, Van Thiel Sandra, 'Accountability After Structural Disaggregation: Comparing Agency Accountability Arrangements' (2015) 93(04) Public Administration 1102

Weber Max, Grundriß der Sozialökonomik: III. Abteilung Wirtschaft und Gesellschaft (J C B Mohr Paul Siebeck 1922) 